\title{
FACILIS DESCENSUS AVERNO: WTO DISPUTE SETTLEMENT AND TRADE-WARS - IS THE WTO HEADING WHERE IT SHOULD?
}

DOI: $\quad 10.24193$ /SUBBiur.66(2021).1.4 Data publicării online: 25.06.2021

Botond-Zoltán PETRES*

\begin{abstract}
Trading is arguably the most important element of our modern society, and its importance in the globalized world is second to none. International commerce nowadays involves more complex supply chains, more sophisticated financial operations, and more economic agents. However, states do remain influential factors in that ecosystem, and together they create the framework of international trade. That framework is closely supervised and controlled by none other, than the World Trade Organization. Although, the creation of the WTO did not guarantee, that there would be no tensions between trading nations. Trade wars cause no surprise for an economist or lawyer assessing international trade. But did the most appropriate organization handle these trade wars right? In this article we will succinctly analyse the current framework and will try to answer whether the Dispute Settlement Mechanism (hereinafter 'DSM') is compatible with all the cases. There is no room for error: if there are certain cases where the DSM only aggravates the problem, then these cases have to be identified and have to be handled with special attention. We are familiar with the disruptive effects of a trade war; hence we are challenged to do our utmost to prevent them - and to rethink what, according to John H. Jackson, has to be a rule-based system.
\end{abstract}

* Botond-Zoltán Petres is a fourth-year student at the Faculty of Law and a first-year master student at the Faculty of Economics and Business Administration, Babeş-Bolyai University, Cluj-Napoca. He can be contacted through his e-mail: botond-zoltan.petres@law.ubbcluj.ro. The author is indebted to Professor Elena Dana BAKO and Professor Alina OPREA for their kind support and supervision, as well as Patricia CîMPIAN for her assistance. The author is thankful for the support by the Collegium Talentum Programme and by ELTE Márton Áron College. All errors remain the author's own. 
Keywords: WTO, Dispute Settlement Body, Dispute Settlement Mechanism, international economic law, trade-wars, supranational institution, international trade.

\title{
FACILIS DESCENSUS AVERNO: RÈGLEMENT DES DIFFÉRENDS DE L'OMC ET GUERRES COMMERCIALES - L'OMC VA-T-ELLE OÙ ELLE DEVRAIT ALLER ?
}

\begin{abstract}
Abstrait : Le commerce est sans doute l'élément le plus important de notre société moderne, et son importance dans le monde globalisé est unique. Le commerce international implique aujourd'hui des chaînes d'approvisionnement plus complexes, des opérations financières plus sophistiquées et plus d'agents économiques. Cependant, les États restent des facteurs influents dans cet écosystème et, ensemble, ils créent le cadre du commerce international. Ce cadre est surveillé et contrôlé par la célèbre organisation internationale, l'Organisation mondiale du commerce. La création de l'OMC n'ait pas garanti toutefois qu'il n'y aurait pas de tensions entre les nations commerçantes. Les guerres commerciales ne surprennent pas un économiste ou un avocat évaluant le commerce international. Mais l'organisation la plus appropriée a-t-elle bien géré ces guerres commerciales ? Dans cet article, nous analyserons succinctement le cadre actuel et tenterons de déterminer si le mécanisme de règlement des différends (ci-après " DSM ») est compatible avec tous les cas. Il n'y a pas de place pour l'erreur : s'il y a des cas dans lesquels le DSM ne fait qu'aggraver le problème, alors ces cas doivent être identifiés et traités avec une attention particulière. Nous connaissons les effets perturbateurs d'une guerre commerciale ; par conséquent, nous sommes mis au défi de faire le mieux possible pour prévenir les guerres - et pour repenser ce qui, selon John H. Jackson, doit être un système fondé sur des règles.

Mots clés : OMC, organe de règlement des différends, mécanisme de règlement des différends, droit économique international, guerres commerciales, institution supranationale, commerce international.
\end{abstract}




\section{Table of Contents}

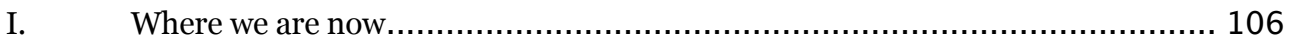

II. C'est la guerre - Trade-wars and the DSM ……........................................ 110

III. 'Nobody can bring you peace but yourself' ………............................... 125

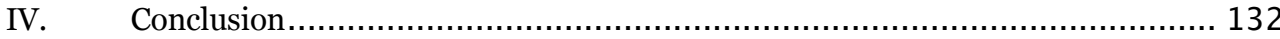

\section{Where we are now}

International commerce nowadays faces the mixture of interests of an increasing number of actors, such as states, international organizations, either governmental or non-governmental ${ }^{1}$, and economic agents. Better than that, the interests of these actors are typically contrary to each other. We must also acknowledge that it is somehow multi-layered, as we can identify different types of motivations, having their roots in politics, economics, and law.

These interests must be reconciled in order to guarantee prosperity and to avoid their escalation. It was rather a conventional wisdom ${ }^{2}$, that an international organization can enhance such reconciliation, if decentralized efforts fail to do so. Creating an international organization regulating trade was a serious post-war incentive of trade negotiators ${ }^{3}$, which was necessary as

\footnotetext{
${ }^{1}$ T. C. LAWTON and S. M. McGuiRE, Supranational governance and corporate strategy: the emerging role of the World Trade Organization. International Business Review, Vol. 10 no. (2), 2001, pp. 217-218.

${ }^{2}$ J. GowA, Explaining the GATT/WTO: Origins and effects. in Lisa L. MARTIN (ed.), The Oxford Handbook of The Political Economy of International Trade, Oxford University Press, New York, 2015, p. 19.

${ }^{3}$ A. NARLIKAR, The World Trade Organization. A very short introduction, Oxford University Press, New York, 2005, p. 22.
} 
those decentralized efforts failed. That incentive became reality, when the WTO was created 4 , and it was built upon a solid foundation, the organizational structure developed under 5 the GATT 6 , which, to the contrary, deemed to be insufficient7. Nowadays, it is considered to be the most important 'intergovernmental organization for world trade'8. Essentially, it is an umbrella organization ${ }^{9}$, supervising the making of trade policy, and its implementation, together with a supranational judicial organ ${ }^{10}$, the Appellate Body (hereinafter 'AB').

The $\mathrm{AB}$ is just an element of the DSM, which has as a main function the settlement of disputes, based on a procedure which involves case-specific panels ${ }^{11}$. The DSM offers a 'quasi-judicial'12 procedure. The whole procedure cannot be described by homogeneity. First, there is a mandatory phase, where political negotiation takes place and the conciliation between the different perspectives. If that fails to produce a result, the issue will head to a Panel,

\footnotetext{
${ }^{4}$ Marrakesh Agreement Establishing the World Trade Organization, 1867 U.N.T.S. 154, 1994.

${ }^{5}$ B. M. Hoekman, and M. M. Kostecki, The political economy of the world trading System. The WTO and Beyond - 3rd Edition. Oxford University Press, New York, 2009, p. 1.

${ }^{6}$ General Agreement on Tariffs and Trade, Oct. 30, 1947, 61 Stat. A-11, 55 U.N.T.S. 194

${ }^{7} \mathrm{G}$. SHELL, Trade legalism and international relations theory: An analysis of the World Trade Organization. Duke Law Journal, Vol. 44, No. 5, 1995. pp. 831-832.

${ }^{8}$ R. SCHAFFER, F. Agusti, and L. J. DHOOGE. International Business Law and Its Environment. 10 ed., Cengage Learning, 2018, p. 237.

${ }^{9}$ G. SHELL, op. cit., p. 832.

10 E. A. Young, Supranational Rulings as Judgments and Precedents, Duke Journal of Comparative \& International Law, Vol. 18, no. 2, 2008, p. 479

11 F. P. Ramos, International and supranational law in translation: from multilingual lawmaking to adjudication, The Translator, Vol. 20, No. 3, 2014, p. 314.

12 N. GRMELOVÁ, Interpretation of the Precautionary Principle by the WTO's Dispute Settlement Body with Respect to the Sanitary and Phytosanitary Agreement, in A. J. BelohlaveK and N. Rozehnalova (eds.), Czech Yearbook of International Law, Volume VIII, Lex Lata, 2017, p. 118.
} 
which can be rather assimilated with international arbitration ${ }^{13}$ : there is a legally binding decision at the end of the procedure (which can only be set aside with the consensus of all the WTO member states), with a possibility to designate members to the panel, an increased confidentiality, and a stage promoting negotiation and settlement, leaving the process in the hands of the parties ${ }^{14}$. Lastly, the AB's phase is rather a ' [']cassation['], not appeal' from the civil law's point of view ${ }^{15}$.

But, even 'the most dynamic of the present-day international tribunals'16 faces challenges. On one hand, the $\mathrm{AB}$ increases the public perception on WTO's legitimacy and improves the dispute settlement under the $\mathrm{WTO}^{17}$. On the other hand, there are certain differences in perspective over how dispute settlement shall work within the $\mathrm{WTO}^{18}$, and what the AB's role shall be. The U.S. blocks the appointment of new $\mathrm{AB}$ members, the term of

\footnotetext{
${ }^{13} \mathrm{G}$. ABI-SAAB, The WTO dispute settlement and general international law, in R. YERXA, and B. WILSON, Key Issues in WTO Dispute Settlement. The first ten years, Cambridge University Press, New York, 2005, p. 8.

${ }^{14}$ Or, as usually stated in French, 'L'arbitrage est la chose des parties'.

${ }^{15}$ G. ABI-SAAB, op. cit., p. 8. Stating, that 'The $[\mathrm{AB}]$ has a kind of supreme court jurisdiction'.

16 C. B. PICKer, International Law's Mixed Heritage: A Common/Civil Law Jurisdiction. Vanderbilt Journal of Transnational Law, Vol. 41, No. 4, 2008, p. 1111.

17 M. WAGNER, The impending demise of the WTO Appellate Body: from centrepiece to historical relic?, University of Wollongong, Faculty of Law, Humanities and the Arts - Papers, 2019. p. 1.

${ }^{18}$ For an exhaustive list of contentious issues see M. WAGNER, op. cit., p. 12 et seq; R. R. BABU, WTO Appellate Body Overreach and the Crisis in the Making: A View from the South, in Lo, C., NAkagaWa, J. and Chen, T., The Appellate Body of the WTO and Its Reform, Springer, 2020, p. 93 et seq. and J. A. Hillman, A Reset of the World Trade Organization's Appellate Body, 2020, Available online at https://www.cfr.org/report/reset-world-trade-organizationsappellate-body, last accessed 01-11-2020.
} 
office for the last sitting judge expires at $30^{\text {th }}$ of November, $2020^{19}$. There are numerous scholars proposing the reform of this pillar of the organization ${ }^{20}$, and among them there are even voices of incontestable authority ${ }^{21}$. Professor Hoekman and Professor Mavroidis argue that panel reports and the overall quality of the dispute settlement can be improved through a proper use of economics ${ }^{22}$. Yet, there are instances, when the leeway guaranteed by economic theory is insufficient, and neither the Dispute Settlement Rules ${ }^{23}$ addresses these situations. A major part of these are the most energetic manifestations of tensions between states: trade wars.

Hereinafter, we will address trade wars, briefly reviewing the most important cases brought to the WTO involving those, and direct our attention to existing flaws when solving such a case. Then, suggestions of potential reforms shall be presented, in order to put the WTO to the place where it is meant to be: as the supranational governing body of international trade.

\footnotetext{
${ }^{19}$ Based on the information available at the website of the WTO, available at https://www.wto.org/english/tratop e/dispu e/ab members descrp e.htm, last accessed 01-11-2020.

${ }^{20}$ R. R. BABU, op. cit., p. 99 et seq.; J. A. Hillman, op. cit.; M. WAGner, op. cit., 19.

${ }^{21}$ B. M. HoEkman, and P. C. Mavroidis, Party like it's 1995: Necessary but not sufficient to resolve WTO Appellate Body crisis, 2019, Available online at Voxeu.org, last accessed 01-112020.

${ }^{22}$ Idem.

23 Dispute Settlement Rules: Understanding on Rules and Procedures Governing the Settlement of Disputes, Marrakesh Agreement Establishing the World Trade Organization, Annex 2, 1869 U.N.T.S. 401, 1994. Hereinafter 'DSU'.
} 


\section{C'est la guerre - Trade-wars and the DSM}

Speaking of wisdoms, the view that commercial activity precludes wars $^{24}$ was a cornerstone of international affairs, on which major international organizations and even the European Union was built. Yet, the concept of war did not entirely disappear: there are voices referring to the post Cold War era as the 'Trade War era'25. We might have changed the scenery from battlegrounds to diplomatic roundtables, and switched instruments from arms to tariff and non-tariff measures and WTO litigation. Still, the broader concept of war is not absent from the international economical and political scenery: '[a] situation in which there is strong competition between opposing sides'26. We might ask about the definition or characteristics of a trade war, but, a question with an importance infinitely higher remains the following: how should the WTO handle these?

Firstly, the question to be answered is whether a trade war falls under the category of a dispute, as set out by the Permanent Court of International Justice: 'a disagreement on a point of law or fact, a conflict of legal views or interests between two persons'27. The criteria, whether such a dispute is

\footnotetext{
${ }^{24}$ E. GARTZKe and J. J. ZhANG, Trade and War, in L. L. MARTin (ed.), op. cit., p. 419.

${ }^{25}$ S. Koshy, From Cold War to Trade War: Neocolonialism and Human Rights, Social Text, No. 58, 1999, p. 16.

${ }^{26}$ Based on one of the definitions in the Cambridge English Dictionary, available online, last accessed at 01-11-2020.

${ }^{27}$ Mavrommatis Palestine Concessions Case, PCIJ. Ser. A., No. 2. para. 11, 1924. On the solution of disputes under international law, see Gy. FÁBIÁN, Nemzetközi Jog, Ed. Hamangiu, Bucharest, 2018, p. 183 et seq.; A. SPAIN, Integration Matters: The Emerging Architecture of International Dispute Resolution. University of Pennsylvania Journal of International Law, Vol. 32, No. 1, 2010.
} 
domestic, or international, is based on 'the legal substance of the dispute'28, and therefore, disputes referring to international law are international disputes. Under the WTO and within the international trading system we talk about trade disputes. However, according to a scholarly opinion ${ }^{29}$, trade wars cannot be claimed to be trade disputes: a trade dispute is judicable within a given institutional framework, in our case, under the $\mathrm{WTO}^{30}$. While a trade war can have its source in a trade dispute, it is based on what Professor Hur calls a 'gloves off approach' ${ }^{31}$. Even if it is 'conducted' under the WTO DSM in form of multiple proceedings, or outside the system, it usually comes handin-hand with a flagrant disregard off the rules of international trade with the scope to achieve a certain economic ${ }^{2}$ or political goal.

Also, similarly with international disputes, it can be bilateral or multilateral. The problem is that the international economy under our current globalized system is essentially interdependent, and therefore even a bilateral trade war can become widespread. It is no wonder, that there are

${ }^{28}$ A. PETERs, International dispute settlement: A network of cooperational duties. European Journal of International Law, Vol. 14, No. 1, 2003, pp. 3-4.

${ }^{29} \mathrm{~N}$. HuR, Historical and strategic concern over the US-China trade war: will they be within the WTO?, Journal of East Asia and International Law, Vol. 11 No. 2, 2018, p. 395

${ }^{30}$ Although, the issue of conflicting jurisdiction of international tribunals has a considerable scholarship, it goes beyond the limits of our assessment. For thorough analysis of the problem, see L. VAUGHAN, Overlapping Jurisdiction in International Tribunals, Australian Year Book of International Law, Vol. 20, 2000; J. PAuwelYN, L. E. SAlles. Forum Shopping Before International Tribunals: (Real) Concerns, (Im)Possible Solutions. Cornell International Law Journal, Vol. 42, 2009.

${ }^{31}$ N. Hur, op. cit., p. 395.

${ }^{32}$ A. Mattoo and R. W. Staiger, Understanding trade wars, in M. A. Crowley (ed.), Trade war. The Clash of Economic Systems Endangering Global Prosperity. CEPR Press, London, 2019, p. 33 et seq. 
interpretations ${ }^{33}$ linking even the UN Security Council to certain world trade wars, affecting the international trading system and indirectly peace.

Hereinafter, we will briefly address some of the most consistent trade wars of the past years, with a part of them addressed through (multiple) WTO proceedings. It is possible, that our current system for the solution of disputes 'veered off track'34. Can this be somehow reversed? We will try to present some crucial elements of these trade wars with the scope to analyze whether the DSM solves trade wars, or, which is more, has the necessary instruments to do so?

Somehow the most controversial dispute, which with its history, exceeds the WTO, is the conflict between the US and the EU35 regarding Airbus and Boeing. It is easily the most illustrative case when it comes to trade wars: it started in the 1970s, both parties being conscious about their violations, which led to a trade agreement in $1992^{36}$. An agreement was later on disregarded, and as a result, we had 5 different WTO proceedings ${ }^{37}$ from 2004 onwards, and retaliation by both parties, which, as some suggests, only

\footnotetext{
${ }^{33}$ N. HuR, op. cit., p. 395 .

${ }^{34}$ M. A. Crowley, Introduction, in M. A. CraWley, op. cit., p. 7.

${ }^{35}$ The author has to highlight that, for the convenience of the reader, within our analysis we will solely refer to the European Union, even if, within a given WTO proceeding, one of the parties were formally the 'European Communities', and not its successor.

${ }^{36}$ D. A. IRVIN and I. PAVCNIK, Airbus Versus Boeing Revisited: International Competition In The Aircraft Market, Working Paper, Available on NBER: http://www.nber.org/papers/w8648, 2001, p. 2

${ }^{37}$ European Communities and Certain member States - Measures Affecting Trade in Large Civil Aircraft, DS316; United States - Measures Affecting Trade in Large Civil Aircraft, DS317; European Communities and Certain Member States - Measures Affecting Trade in Large Civil Aircraft (Second Complaint), DS347; United States - Measures Affecting Trade in Large Civil Aircraft - Second Complaint, DS353; and United States - Conditional Tax Incentives for Large Civil Aircraft, DS487.
} 
aggravates the situation ${ }^{3}$. It is one of the largest commercial disputes ever referred to the WTO, and one of the most expensive cases ${ }^{39}$ as well. The dispute was triggered by the unusual trait of the large jet airliner market, and namely, that it is about as far as one can get from the standard trade theory paradigm of static constant returns and price-taking competition'40, which led to government subsidies ${ }^{41}$ for both sides.

However, subsidies were addressed even by the bilateral agreement ${ }^{42}$ between the EU and the US. The problem was that the parties 'could not agree on important points and refrained from defining substantial and decisive terms'43. The reason is obvious, as the agreement was rather political, and it hardly had economic foundation 44 . So, the agreement was rather a delay of the upcoming conflict, which culminated in form of the WTO proceedings.

${ }^{38}$ See R. HuDEc, Broadening the Scope of Remedies in the WTO Dispute Settlement: Issues and Lessons from the Practice of Other International Court and Tribunals, 2000, pp. 21-22, available online http://www.worldtradelaw.net/document.php?id=articles/hudecremedies.pdf, last accessed at 12-11-2020. ('In economic terms, the balancing rationale for retaliation is a fiction'.)

${ }^{39}$ N. MEIER-KaIENBURG, The WTO's toughest case: An examination of the effectiveness of the WTO dispute resolution procedure in the airbus-boeing dispute over aircraft subsidies. Journal of Air Law and Commerce, Vol. 71, No. 2, 2006, p. 194.

${ }^{40}$ R. BALdWin and P. KRUgman, Industrial Policy and International Competition in WideBodied Jet Aircraft, in R. BALDWIN (ed.), Trade Policy Issues and Empirical Analysis, University of Chicago Press, Chicago, 1988. p. 45

${ }^{41}$ J. Scherpenberg and N. Hausséguy, The Airbus-Boeing Dispute: Not for the WTO to Solve, German Institute for International and Security Affairs, SWP Comments, No. 30, 2005, p. 2.

${ }^{42}$ H. Robertson, No Sign of Landing: Airbus, Boeing, the WTO, and the Expanding Large Civil Aircraft Battle, Working Paper, 2018, p. 7. Available on SSRN: https://papers.ssrn.com/sol3/papers.cfm?abstract id=3114942, last accessed at 01-11-2020.

${ }^{43}$ N. Meier-Kaienburg, op. cit., p. 200.

44 C. E. BARFIELD, Avoiding an Air War, 2004, available online at https://www.aei.org/articles/avoiding-an-air-war/, last accessed o1-11-2020.

\section{3}


Yet, after more than 15 years of litigation, and tariffs imposed by the US45, as well as tariffs underway to be imposed by the EU46, we have no clairvoyance about a potential, long-lasting 'peace'.

Professor Garten called it as early as 2005 that under the WTO sanctions will be levied upon both party ${ }^{47}$, and that the WTO is not equipped to handle such a case. Concerns about the WTO not being a proper forum for the conflict were voiced by scholars ${ }^{48}$. Although these voices, the proceedings were advancing, and as mentioned above, retaliation is in place in case of both parties. A retaliation which ' $[\mathrm{I}] \mathrm{n}$ economic terms (...) amounts to shooting oneself in the foot'49. Even after a 'settlement', the trade-war is well underway, impacting our international trading system ${ }^{50}$, without a prospect for a definitive solution inside the foreseeable future ${ }^{51}$. Negotiation and a new trade

45 Press Release of the Office of the United States Trade Representative, 2019, available online at https://ustr.gov/about-us/policy-offices/press-office/press-releases/2019/october/uswins-75-billion-award-airbus, last accessed at 12-11-2020

46 Press Release of the European Commission, 2020, available online at https://ec.europa.eu/commission/presscorner/detail/en/IP $20 \quad$ 2048, last accessed at 12-112020.

${ }^{47}$ J. GARTEN, The Big Blowout: Why the Airbus-Boeing case could wreck the WTO, and how to stop it, Newsweek International, 2005.

${ }^{48}$ N. MeIER-KAIENBurg, op. cit., p. 237 et seq.; J. SCHERPENBERG and N. HAUSSÉGUY, op. cit., pp. 4-5, the authors call the WTO a 'secondary theater' in the dispute, while they argue that a foreseeable retaliation of the parties is just an 'impractical result'; Ö. ÇALIŞKAN, An Analysis of the Airbus-Boeing Dispute From the Perspective of the WTO Process, EGE Academic Review, Vol. 10, no. 4. 2010. pp. 1135-1137.

${ }^{49}$ M. Busch and K. Pelc, Dispute Settlement in the WTO, in L. Martin (ed.), op. cit., p. 404.

50 Ö. ÇALIŞKAN, op. cit., p. 1137.

${ }^{51}$ S. Chanda, The Battle of the Big Boys: A Critical Analysis of the Boeing Airbus Dispute Before the WTO, Working Paper, 2011, p. 17. Available on SSRN: https://papers.ssrn.com/sol3/papers.cfm?abstract id=1944.588, last accessed at 12-11-2020.

\section{4}


agreement might be a solution, as identified by some scholars ${ }^{52}$, but the WTO acting as a 'judge', rather than the controlling body of international trade does not really help.

The battle between Airbus and Boeing is not the only case rising the tensions in EU-US trade relations. There are at least four additional 'mini trade wars', based on the excellent economic analysis of Professor Breuss 53 . The four cases to be analysed, while we remain assessing the dynamics of EUUS trade wars are the hormones case ${ }^{54}$, the bananas case ${ }^{55}$, the Foreign Sales Corporation case ${ }^{56}$, and the steel case ${ }^{57}$.

In the hormones case, unlike the Airbus-Boeing dispute, the initial violation of WTO law was unilateral, as we had a trade policy implemented by the EU and contested by both the US and Canada ${ }^{58}$. Prior to the proceeding,

\footnotetext{
${ }^{52}$ H. RoberTson, op. cit., p. 25 et seq; J. KiEnstra, Cleared for landing: Airbus, boeing and the WTO dispute over subsidies to large civil aircraft. Northwestern Journal of International Law \& Business, Vol. 32, No. 3. 2012. pp. 604-605.

${ }^{53} \mathrm{~F}$. BREUSS, WTO dispute settlement: an economic analysis of four EU-US mini trade warsa survey. Journal of Industry, Competition and Trade, Vol. 4, No. 4, 2004, pp. 282-309. BREUSs helds the economic impact of the cases under serious scrutiny and proposes certain modification in case of possible sanctions.

${ }^{54}$ European Communities - Measures Concerning Meat and Meat Products (Hormones), DS26, hereinafter the 'hormones' case.

55 European Communities - Regime for the Importation, Sale and Distribution of Bananas, DS27, hereinafter the 'bananas case'.

${ }^{56}$ United States - Tax Treatment for 'Foreign Sales Corporations', DS108, hereinafter the 'FSC case'.

${ }^{57}$ United States - Definitive Safeguard Measures on Imports of Certain Steel Products, DS252, hereinafter the 'steel case'.

${ }^{58}$ S. BERMANn, EC-Hormones and the Case for an Express WTO Postretaliation Procedure, Columbia Law Review Vol. 107, No. 1, 2007. passim.
} 
we had years when the parties negotiated for a settlement59, but their endeavour did not produce tangible results. Some growth hormones were banned in $1981^{60}$ due to food safety concerns ${ }^{61}$, and then, definitively in 1988 by the EU, which limited trade in case of meat and related products. Later on, the case reached the WTO in 1996, after a panel's establishment under the GATT was blocked by the EU62. The AB took a decision in the case, finding that the EU did violate WTO law. Of course, retaliation was implemented in this case too by both the US and Canada ${ }^{63}$. Although, that did not bar the EU to maintain the conflict, as they did not even reconsider the ban ${ }^{64}$, not to speak about reversing their decision, until a final, joint understanding was reached in $2013^{65}$. Professor Princen talks about a 'relative ineffectiveness' of the WTO law, pointing out a trade-off in political costs ${ }^{66}$ related to the reversal of the policy against disrespecting the WTO law, with the later being the "more suitable' option for the EU. That alone speaks volumes of the multilateral, liberal trading system and its enforceability.

59 J. Peel, R. Nelson, and L. Godden, GMO trade wars: the submissions in the EC-GMO dispute in the WTO. Melbourne Journal of International Law, Vol. 6, 2005, p. 142.

60 Council Directive 81/602/EEC of 31 July 1981 concerning the prohibition of certain substances having a hormonal action and of any substances having a thyrostatic action, Official Journal L222/32.

${ }^{61}$ R. BAILEY, The looming trade war over plant biotechnology. Cato Institute, 2002, p. 9

${ }^{62}$ S. PRINCEN, EC compliance with WTO law: the interplay of law and politics. European Journal of International Law, Vol. 15, No. 3, 2004, pp. 567-568.

${ }^{63}$ F. Breuss, op. cit., p. 283; S. Bermann, op. cit., p. 139.

${ }^{64}$ S. PRINCEN, op cit., p. 570

${ }^{65}$ WT/DS26/29, Joint Communication from the European Communities and the United States, 2014,

${ }^{66}$ S. PRINCEN, op. cit., p. 570. 
The banana dispute, or the 'Trade case of the Decade', ${ }^{67}$ during the 1990s, began in 1993. Several postcolonial countries from Africa, the Caribbean and the Pacific area were beneficiaries of a preferential treatment for banana exports by some European countries ${ }^{68}$. There was no harmonization of the treatment of bananas within the European Union, with several international treaties setting up the privileges for the abovementioned states, with the Fourth Lomé Convention ${ }^{69}$ being the one in place at the moment the case was referred to the WTO. Furthermore, a five-year waiver ${ }^{70}$ was adopted by the Contracting Parties of the GATT, pursuant to the request of the EU.

The WTO proceeding started in 1996, with the panels finding the EU's practice illegal under WTO law ${ }^{71}$ as of 1997. The EU appealed the decision, but the $\mathrm{AB}$ upheld most of the considerations leading to the panel decision ${ }^{72}$. At that point, the EU either had to comply with the AB's decision or it could possibly face sanctions. Consultations were requested by the EU, seeking a 15 months and one week period to implement the $\mathrm{AB}$ decision, which was later on granted through an arbitration procedure ${ }^{73}$. However, as neither the US

\footnotetext{
${ }^{67}$ M. SALAS and J. JACKSON, Procedural overview of the WTO EC-banana dispute. Journal of International Economic Law, Vol. 3, No. 1, 2000, p. 145.

${ }^{68}$ B. BRIMEYER, Bananas, beef, and compliance in the world trade organization: the inability of the WO dispute settlement process to achieve compliance from superpower nations. Minnesota Journal of Global Trade, Vol. 10, 2001. p. 147 as well as note 136.

${ }^{69}$ Forth ACP-EEC Convention on Lomé, 15 December 1989, 29 ILM 783, 1990.

${ }^{70}$ Zs. BessKó, Going Bananas over EEC Preferences: A Look at the Banana Trade War and the WTO's Understanding on Rules and Procedures Governing the Settlement of Disputes. Case Western Reserve Journal of International Law, Vol. 28, Issue 2, 1996, p. 265.

${ }^{71}$ F. BREUSS, op. cit., p. 290.

72 B. BRIMEYER, op. cit., p. 149.

${ }^{73}$ M. SAlas and J. JaCkSON, op. cit., p. 152.
} 
and neither the other South and Central American states were not satisfied by the implementation, a request for a new ruling was submitted, which lead to the first instance ${ }^{74}$ of a settlement and its implementation to be judged by a WTO Panel. As the EU tried to delay the second decision of the Panel on procedural grounds75, the US asked for WTO authorization for tariff concessions to be suspended $7^{76}$, covering trade in an amount of US $\$ 520$ million. An Arbitration procedure was requested to reassess the level of sanctions, which further delayed the process, leading to the US announcing $100 \%$ duties for this amount 77 , leading to high-level political clashes between the two parties. Subsequently, the arbitration procedure determined the value of allowed retaliation to be substantially lower ${ }^{78}$, issuing a decision when the Panel's retrial was well underway. The Panel's final decision declared that the EU did not comply with its obligations ${ }^{79}$, The EU, however, did give in later on, for reasons ${ }^{80}$ relating to the next phase of WTO negotiations and for the credibility of the WTO system, but the case evidenced the problem to determine the fair amount of retaliation, if imposed, and also the inequality of sanctioning power between developed and developing countries (such as Ecuador $^{81}$, in the present case).

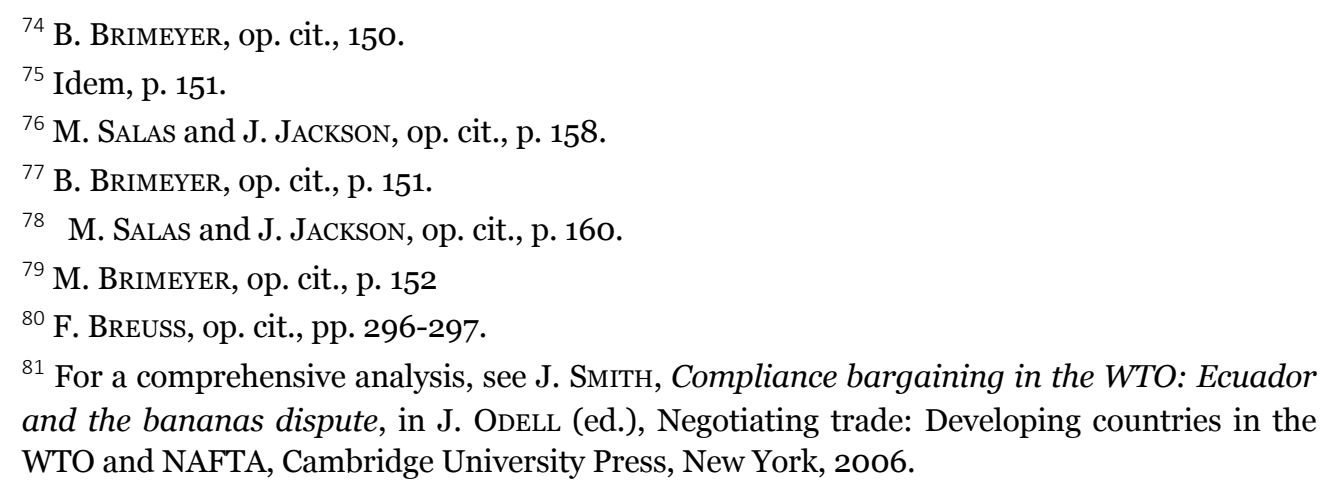


Another antagonism leaving a mark on the EU-US trade relations and on the international trading system was due to certain tax exemptions conferred for exporting companies from the US, which, as possible illegal export subsidies $^{82}$ violated international obligations, and affected European companies. The FSC regime had a predecessor, namely the 'Domestic International Sales Corporations' rules $^{83}$, entering into force in 1971. This tax scheme, the so-called DISC, was referred to a Panel under the GATT, and the proceeding ended in 1981, with the Panel declaring it contrary ${ }^{84}$ to the GATT. The EU, together with some other states requested consultations ${ }^{85}$ in 1997, which led to the creation of a Panel after they could not reach an agreement with Washington. The EU emerged victorious, as the Panel confirmed the EU's perspective ${ }^{86}$ at $8^{\text {th }}$ of October 1999 , which was upheld by the $\mathrm{AB}^{87}$ as of $24^{\text {th }}$ of February 2000. Later, a modified version of the FSC was enacted ${ }^{88}$, which was once again contested by the EU. Moreover, the EU went forward with a possible retaliation in a quantum of roughly 4 billion dollars ${ }^{89}$, the largest claim up until that point.

82 A. Commins, World Trade Organization's Decision in United States - Tax Treatment for Foreign Sales Corporations: Round Three in the Transatlantic Tax Dispute, North Carolina Journal of International Law and Commercial Regulation, Vol. 27, No. 2, 2001, p. 364

${ }^{83}$ B. HockING and S. McGuIRE, Government-Business Strategies in EU-US Economic Relation: The Lessons of the Foreign Sales Corporation Issue, Journal of Common Market Studies, Vol. 40, No. 3, 2002, p. 450

${ }^{84}$ F. Breuss, op. cit., p. 297.

${ }^{85}$ A. Commins, op. cit., pp. 365-366.

${ }^{86}$ H. Clark, A. Bogran and H. HANSOn, The WTO Ruling on Foreign Sales Corporations: Costliest Battle Yet in an Escalating Trade War between the United States and the European Union, Minnesota Journal of International Law. Vol. 3, 2001, p. 293.

${ }^{87}$ F. BREUSS, op. cit., p. 297.

${ }^{88}$ A. Commins, op. cit., p. 367.

${ }^{89}$ H. Clark et. al., op. cit., p. 294. 
The WTO stalled9o the retaliation until a decision was made by the second panel. The Panel confirmed the EU's standpoint, which was followed by an arbitration procedure determining the amount of retaliation ${ }^{91}$. The US was obviously disappointed with voices foreseeing its departure from the WTO ${ }^{92}$. A period of retaliation followed upon the authorization of the WTO on $7^{\text {th }}$ of May $2003^{93}$, which were in place for 2 years, until there was a mutually accepted implementation of a new regime as of May 200694. The saga went on for more than thirty years but, in this case, retaliation did help to some extent. However, the damage done in case of non-EU countries was never determined, levelling the playground only happened ex nunc for them. Also, it might be erroneous to declare that the country choosing to implement a WTO decision did it solely because of their 'utter respect' towards international trade. The five cases addressed by us were contemporary issues, meaning that a concession in one of them might just be interpreted differently when one looks at the bigger picture.

If the abovementioned examples were adhering to a conventional concept of a trade war, lasting for years if not for decades, and severely damaging economies on the way, the steel case could be rather labeled as a blitzkrieg. The first 'act of war' came from the US in March 2002, when protective import duties were imposed on 14 types of steel products95, as a

\footnotetext{
${ }^{90}$ Ibidem.

${ }^{91}$ F. BReuss, op. cit., pp. 297-298.

${ }^{92}$ H. ClaRK et. al., op. cit., p. 312.

${ }^{93}$ F. BREUSS, op. cit., p. 298.

${ }^{94}$ https://www.wto.org/english/tratop e/dispu e/cases e/ds108 e.htm, Last accessed at 1511-2020.

${ }^{95}$ H. MAHNCKE, US Steel Tariffs and the WTO Dispute Resolution Mechanism. Leiden Journal of International Law, Vol. 17, No.3, 2004, p. 615.
} 
safeguard measure. The EU signalled its intention to challenge the duties in advance ${ }^{96}$. Later on, besides formally stating its request to start a WTO procedure (along with 7 other states) it also introduced its own safeguard measures, targeting US steel products ${ }^{97}$. As consultations led to no result, a WTO Panel was established, which ruled that the US measures were illegal ${ }^{98}$. An appeal went forward by the US, with the $\mathrm{AB}$ condemning the measures 99 definitively. Due to the countermeasures and the WTO decision, the measures were voided ${ }^{100}$ as of December 2003.

There is a narrative, which could state, that the world most powerful country had a proceeding against it at an international court, lost, and then complied ${ }^{101}$. However, before reaching an ecstasy, this narrative might miss some legal and political determinants of the result - as we all do in case of WTO decisions, when the motivation to comply 'is not always genuine'102. A high domestic political motivation ${ }^{103}$ was to be identified both in the introduction and the dismantling of these steel tariffs. Albeit, these political

${ }^{96} \mathrm{R}$. READ, The EU-US WTO steel dispute: the political economy of protection and the efficacy of the WTO Dispute Settlement Understanding, in N. PERDIKIS, R. READ (eds.), The WTO and the regulation of international trade: Recent trade disputes between the European Union and the United States, Edward Elgar, Cheltenham, 2005, p. 156.

${ }^{97}$ F. BREUSS, op. cit., p. 306.

${ }^{98}$ H. MAHNCKe, p. 615.

${ }^{99}$ Y. JUNG and E. KANG, Toward an Ideal WTO Safeguards Regime-Lessons from US-Steel. The International Lawyer, Vol. 38, p. 919.

${ }^{100}$ Idem, p. 920

${ }^{101}$ H. MAHNCKe, op. cit., p. 616.

102 Ibidem.

${ }^{103}$ F. BREUSS, op. cit., p. 304. As, we shall not forget, that the measures imposed by the US were preceding the US presidential election, possibly with an aim to influence it, and were voided in 'short time' after it ended. 
considerations were thought to be eliminated ${ }^{104}$ from a rule-based system, the WTO was created to be. The steel case did not just demonstrate the contrary, but highlighted, that the EU is the only challenger ${ }^{105}$ to limit the unilateral actions of Washington. Or, is it?

We shall not forget Beijing. Even that China was not an original member of the GATT (as it only had an observer status) or the WTO, it is a key player in international trade. That is illustrated best by the fact, that after the Chinese ascension to the WTO in 2001 ${ }^{106}$, China was involved in 251 WTO proceedings of the total 597 as of December 2020, a figure only topped by Japan, the EU, and the US. That is in line with an economic research, which finds, that outside of the economic capacity of a member state, the reliance on the DS is not affected by the length of membership in the given organization, but instead by its previous experiences with the procedure ${ }^{107}$. Based on this, the abovementioned figure highlights a natural decision from China, as in order to benefit from the WTO membership and the possibilities of the DSM, it had to establish its own policies and patterns based on first-hand experience.

However, it remains a question whether under the current multilateral system there is a place for any action against blatantly protectionist policies. This is well illustrated by the infamous China-US trade war, or, more

\footnotetext{
${ }^{104}$ H. MAHNCKE, op. cit., p. 623.

${ }^{105}$ R. READ, op. cit., p. 172.

${ }^{106}$ Aimin Chen, China One Year After its WTO Entry, in S. BAO, S. Lin, and C. ZhaO (eds.), The Chinese Economy after WTO Accession, Ashgate, Wiltshire, 2006, p. 17.

107 H. W. LEE, Legalization and dispute settlement benefits: The case of the GATT/WTO, Review of International Organizations, Vol. 14., 2019, p. 502.
} 
plastically, the battle between the 'dragon' and the 'eagle'108. Everything started when the current US administration started imposing high tariffs on certain products ${ }^{109}$, relying on certain domestic regulations. The first two wave affected some third parties as well, but the tariffs war escalated mainly between China and the US, as China was willing to retaliate ${ }^{110}$. In two years, there were numerous occasions when tariff levels were increased or new tariffs were imposed, and as a result, the average tariff for $2 / 3$ of Chinese products exported to the US rose from $3 \%$ to $20 \%$, while, average tariff in case of nearly $2 / 3$ of US products followed a similar trend, reaching $20.5 \%$, upon being exported to China ${ }^{111}$. The worth of these tariffs on each side easily surmounts any past trade conflict. Therefore, from a relation of codependence and symbiotic cooperation ${ }^{112}$, we are heading towards a commercial Cool-war. Even if a global trade war ${ }^{113}$ seems evitable, the impacts of the conflict can likely spill over and change the WTO. Professor Bown ${ }^{114}$

108 A. Kuerstein, The Eagle And The Dragon: A Review Of Cool War: The Future Of Global Competition, Denver Journal of International Law \& Policy, Vol. 43, No. 3, 2015, p. 311, stating that ' $t]$ he rapport between

these two countries will likely determine their courses and that of international law and relations in general for decades to come.'

${ }^{109}$ T. A. AdEKOLA, US-China trade war and the WTO dispute settlement mechanism, Journal of International Trade Law and Policy, Vol. 18, Is. 3, 2019, p. 127 et seq.

${ }^{110}$ N. HuR, op. cit., p. 409.

${ }^{111}$ I. DobozI, War And Peace In USA-China Trade, Köz-gazdaság, Vol. 15, No. 1, 2020, p. 145146. The article also contains an excellent analysis of trade balance and its role.

112 S. PenceA, Us-China Trade War And Its Potential Consequences, Revista de Economie Mondială, Vol. 11, No. 1, 2019, p. 5 .

${ }^{113}$ V. CÂMPEANU, What Comes Next? A Global Trade War Or The Renegotiation Of Us Trade Agreements?, Revista de Economie Mondială, Vol. 10, No. 1, 2018, p. 55 et seq.

${ }^{114}$ C. P. Bown, The 2018 trade war and the end of dispute settlement as we knew it, in $\mathrm{M}$. Crowley (ed.), Trade War: The Clash of Economic Systems Endangering Global Prosperity, CEPR Press, 2019, p. 21. 
reflects on this, while questioning whether the shortcomings of the dispute settlement caused the trade war or the trade war tore the DS system down?

The question stands, as, 'le juge naturel'115 to reconcile between the parties could have been the WTO. China, besides entering a tariff war against the US, also tried to solve the issue within the multilateral trade regime, claiming, that the domestic regulation allowing the US contravenes WTO law $^{116}$. A Panel report was circulated, but it was appealed by the US, and as we know it, due to the US block of new AB members' appointment, there is little to no chance that the WTO procedure will be fruitful in the short-term. The DS in this case was a possibility to have a transparent process for the conciliation of contrary viewpoints upon trade technicalities, and thus preventing a 'full-blown trade war', which could take us back to the 'preGATT days of (...) unbridled foreign retaliation'117.

In December 2019, a bilateral agreement was adopted, which meant that existing tariffs will be lowered by the US while new tariffs will not be adopted, and that China will export more to lower the negative US trade balance $^{118}$. Also, the US Election in 2020 and its result can also serve as a potential source of hope. Contrarily, there are voices suggesting, that the actual solution of the trade war has nothing to do with trade balance, but with the different economic approaches ${ }^{119}$ and their coexistence within

\footnotetext{
${ }^{115}$ Or, the English correspondent of the French concept, 'the natural forum' for a given dispute. See J. PAuWELYN, L. E. Salles, op. cit., p. 115.

${ }^{116}$ United States - Tariff Measures on Certain Goods from China, DS543.

117 C. P. Bown, U.S.-China Trade Conflicts and the Future of the WTO, Fletcher Forum of World Affairs, Vol. 33, No. 1, 2009, p. 46.

${ }^{118}$ I. DobOZI, op. cit., 155 .

${ }^{119}$ N. HuR, op. cit., p. 411.
} 
international trade. Nonetheless, the US chose a different path than the DSM, as they considered it ill-equipped against an alleged Chinese subsidization ${ }^{120}$. Such a difference in economic approach is unavoidable, along with a contrast between the verdict of international economics and the domestic economic approach of a certain foreign policy, but solely that should not allow a member to 'opt-out' of dispute settlement. Moreover, the whole trade war might indicate the end of US leadership, and the damaged system of the WTO might not be able to handle global trade anymore, which is so much more ${ }^{121}$ than just the US.

Although, there are some other instances ${ }^{122}$, when a potential trade conflict could be rather characterized as a trade war, based on the intensity and the instruments used (which can go as far as a flagrant ignorance of WTO law or even binding WTO decisions) by the conflicting parties.

\section{III. 'Nobody can bring you peace but yourself' 123}

On a short essay about trade wars, we shall also talk about peace. The economic doctrine is lately unequivocal about the fact, that the WTO

${ }^{120}$ C. P. Bown, The 2018 trade war..., op. cit., p. 24 .
${ }^{121}$ C. P. Bown, D. A. IRWIN, Trump's Assault on the Global Trading System: And Why
Decoupling from China Will Change Everything, Foreign Affairs, Vol. 98, No. 5, 2019, p. 131.
${ }^{122}$ Such as, for example, the dispute between Mexico and the US on cross-border trucking. See
K. W. ALEXANDER, B. J. SoukUP, Obama's first trade war: The US-Mexico cross-border
trucking dispute and the implications of strategic cross-sector retaliation on US compliance
under NAFTA, Berkeley Journal of International Law, Vol. 28, 2010.
${ }^{123}$ The title of the chapter is a famous quote, see Ralph Waldo EMERSON, Self Reliance, available
online https://archive.vcu.edu/english/engweb/transcendentalism/authors/emerson/essays/selfrel iance.html. 
promotes trade ${ }^{124}$, and that liberalization is beneficial for each involved party $^{125}$. Be that as it may, descending to hell might be much easier, against all the preference of traders and specialists of international trade. The WTO is ahead of a considerable reform, and it cannot be stressed enough what is at stake. It is a utopian assumption, that even after the current impasse will be over, there will be no incentives by different members to boycott the organization's functioning, mainly its DSM. Therefore, there is an urging need for safeguards. International trade might be a topic of domestic politics, but domestic politics shall not be a factor as important that it can eventually become a fly in the ointment.

First of all, it is questionable whether special cases, just as some we mentioned above need a special treatment, such as a different procedure, or, even special instruments, even though establishing a criterion might be challenging in the beginning. The system might function flawlessly, some cases might shatter it through weakening the authority of the Dispute Settlement Body and through questioning the efficiency of the procedure itself. That is recalled by Professors Hoekman and Kostecki, when they express, that 'the small number of high-profile disputes that do not get resolved - such as EC-Hormones - tend to obscure the many ways in which

\footnotetext{
${ }^{124}$ A. Subramanian, S.-J. WEI, The WTO promotes trade, strongly but unevenly, Journal of International Economics, Vol. 72, 2006, p. 173, claiming, that the GATT/ WTO has done a splendid job of promoting trade'; M. LARCH, J.-A. MonteIro, R. PIERMartini and Y. V. Yotov, On the effects of GATT/WTO membership on trade: They are positive and large after all, WTO Staff Working Paper, No. ERSD-2019-09, 2019, passim. Available online at http://hdl.handle.net/10419/200403.

${ }^{125}$ M. LARCH et. al., op. cit., p. 17, setting it forth that 'GATT/WTO membership has increased trade between (...) non-member countries by about 88\%'.
} 
the WTO works well (...)'126. The standard procedure might be based more upon consultation, and the parties might be responsible for how the case is conducted, but in certain issues the WTO shall have a more active role.

Secondly, in a strict relation with these special cases, we have to remind ourselves of possible remedies instituted by the DSU. First of all, retaliation is not a widespread phenomenon ${ }^{127}$, as most of the disputes are solved without reaching the retaliation phase ${ }^{128}$. Contrarily, most of the trade wars went against this current, as retaliation was a factor of a 'cease-fire'. That perfectly falls into place, if we consider, that ' $[t]$ he sole aim of the WTO dispute settlement mechanism is to bring a member's inconsistent measure into consistency with the WTO rules'129. Albeit, there are certain problems within the current system of retaliation. As Breuss points it out, the level of possible retaliation is really hard to be determined in practice, and moreover, that 'the damage calculated by WTO arbitrators may finally be quite different from the overall economic impact'130. In addition, it favors larger countries because of their better access, and it also functions only ex nunc, past wrongdoings might go unpunished ${ }^{131}$. Moreover, the current form of retaliation is economically inefficient ${ }^{132}$. Hudec denies the existence of a

\footnotetext{
${ }^{126}$ B. M. Hoekman, M. M. Kostecki, The political economy of the world trading System. The WTO and Beyond - 3rd Edition. Oxford University Press, New York, 2009, p. 665.

${ }^{127}$ M. L. BusCH and K. J. PELC, op. cit., p. 404.

${ }^{128}$ C. P. Bown, D. A. Irwin, op. cit., p. 131.

${ }^{129}$ T. A. AdEKola, op. cit., p. 130.

${ }^{130}$ F. BREUSS, op. cit., p. 307.

${ }^{131}$ Ibidem.

${ }^{132} \mathrm{~B}$. Mercurio, Why compensation cannot replace trade retaliation in the WTO Dispute Settlement Understanding, World Trade Review, Vol. 8, No. 2, 2009, p. 4.
} 
balancing rationale, and points out, that retaliation is rather a political tool ${ }^{133}$. We shall reflect on the 'apparent irony'134 of such a measure, accepted by an organization built on free trade, adding insult to injury.

Bearing these in mind, it comes as no surprise that numerous proposals were brought forward, such as a collective retaliation, or mandatory compensation $^{135}$. Built on an experience from the banana dispute (where Ecuador failed to retaliate ${ }^{136}$ ), the steel case (which was a conflict too short to imply retaliations, but long enough to inflict an economic loss), or the tradewar between US and China (where without a retrospective monetary compensation the lost confidence might not be restored ${ }^{137}$ ), a compensatory framework might be appealing. However, Mercurio ${ }^{138}$ finds the Achilles heel of compensations, namely, that, compared with a trade sanction enforceable by a complainant, compensation has to be offered by the non-complying member, and a lack of cooperation might imply an additional mechanism for

\footnotetext{
${ }^{133}$ R. HUDEC, op. cit., p. 22.

134 M. L. Busch and K. J. Pelc, op. cit., pp. 404-405. One shall also mention that the 'sanctioning power' of the WTO is indirect, as it can only accept eventual 'countermeasures' (retaliation), which will be imposed by the states, participating in a given dispute settlement procedure, but there are no direct sanctions, imposed by the WTO - an idea which would be somehow contrary to the principles of international law.

135 M. BRonckers, N. VAN DEN BRoEK, Financial compensation in the WTO - improving the remedies of WTO dispute settlement, Journal of International Economic Law, Vol. 8 no. 1, 2005, pp. 106-107. We must also note that art. 22.1 institutes voluntary compensation besides trade retaliation.

${ }^{136}$ See Contribution of Ecuador to the Improvement of the Dispute Settlement Understanding of the WTO, TN/DS/W/9, 2002, arguing that retaliation 'inflict[s] greater injury on the complaining part'.

${ }^{137}$ T. A. ADEKOLA, op. cit., p. 131.

${ }^{138}$ B. MERCURIO, op. cit., p. 15 .
} 
enforcement. Also, Schaffer triggers a warning, namely, that 'strong remedies could arm nationalists' ${ }^{139}$.

So, where to, from here? We tend to believe that the current framework rather needs a fine tune, than a complete reshaping. If the procedure solves the majority of the disputes, and only some 'outliers' ${ }^{140}$ reach a point where a Panel or an $\mathrm{AB}$ decision is not enough, but some of these cases are not solved even after retaliation is put into place (such as the hormones case), or retaliation only escalates the problem (such as in the bilateralretaliation of the Airbus-Boeing trade-war), then the most appropriate is to be concerned about these cases, and leave the system to function on other instances. In most of the cases, we are witnessing a situation, when '[e]ach side wants to keep its sovereign prerogatives intact; each guards its sovereignty jealously'141. However, guarding ones sovereignty sounds ridicule in a situation of an abuse $\mathrm{e}^{142}$ of the DSM and its procedures. Therefore, the crucial modification, as the author sees it, is rather the elimination of potential escape clauses through what dispute settlement can be stalled, or even impaired. It might seem, that solving the issue of zeroing ${ }^{143}$ and the current

${ }^{139}$ G. C. SHAFFER, How to make the WTO dispute settlement system work for developing countries: some proactive developing country strategies. ICTSD Resource Paper No. 5, 2003, p. 43.

${ }^{140}$ C. P. Bown, S. KeYNES, Why Trump shot the Sheriffs: The end of WTO dispute settlement 1.o. Peterson Institute for International Economics Working Paper, (20-4), 2020, p. 10. On the same issue, see M. L. Busch and K. J. Pelc, op. cit., p. 402, reaching the conclusion that '[i]n truth, retaliation never happens', as only 1 percent of the cases reaches this phase.

${ }^{141}$ H. Clark, et. al., op. cit., p. 317.

${ }^{142}$ H. MAHNCKE, op. cit., pp. 624-625.

${ }^{143}$ For an analysis of the conflict, see P. C. MAVRoIDIs, T. J. PrusA, Die another day: Zeroing in on targeted dumping - Did the AB hit the mark in US-washing machines?, World Trade Review, Vol. 17, 2018, p. 247 et seq. For a detailed analysis of zeroing, see C. P. Bown, T. J. 
AB blockage, 'the shot sheriffs' ${ }^{144}$, will bring back the former glory of the WTO. We just tend, to ignore, that as nations compete under an international trade regime, incentives of potential trade skirmishes, providing just small gains will always be pursued. The majority of these reach a nonviolent conclusion, and even if they do not increase trade ${ }^{145}$, they might optimize international economy through gains of efficiency. However, there should be a room for error for the WTO too: conferring a possibility to effectively counteract the small minority, where the parties are not afraid to go for 'blood'.

As a potential orientation towards compensation or retaliation is unclear yet, we know that 'neither remedies the problem of the offending industry escaping [']punishment['] while an innocent industry suffers' ${ }^{\prime 146}$. But what if we try to eliminate potential consequences in advance, so that no temporary advantage can be gained, during a length procedure? The WTO shall have a mean to allow the temporary suspension of concessions, prior to a binding decision, if a certain doubt exists over the legality of the measures, or, more easily, if the measures are flagrantly against the WTO law. That has the possibility to level the playground at a much earlier moment of a WTO procedure's life cycle, while also limits the potential damages and trade distortion caused. This variant might also be more easy to implement than a potential retrospective monetary compensation ${ }^{147}$, even if certain Free Trade

Prusa, U.S. Anti-dumping: Much Ado about Zeroing, in W. Martin, A. Mattoo (eds.), Unfinished Business? The WTO's Doha Agenda, CEPR and The World Bank, 2011, passim.

144 S. Chaudoin, J. KuCIK, and K. PELc, Do WTO disputes actually increase trade? International Studies Quarterly, Vol. 6o, No. 2, 2016, p. 305.

${ }^{145}$ C. P. Bown, S. Keynes, op. cit., p. 22

${ }^{146}$ B. MERCURIO, op. cit., p. 22.

${ }^{147}$ T. A. Adekola, op. cit., p. 132. 
Agreements ${ }^{148}$ adopted such a solution, it might be a long-shot to except a political consensus in that sense.

A proactive role is perhaps against the current legal nature of the DSM, and a proactive approach, as an idea might cause controversy. However, a long-lasting phase of retaliation is in favour of none. After all, we are talking about international trade, due to the multiplicity of interests, an action shall not be deemed forever in the hand of the parties. Whenever a binding decision is reached, the WTO might be required to step-in, and call the Legislative Arm to action ${ }^{149}$. A binding decision does not serve as a perfect cure, even if retaliation starts to be applied, as demonstrated by the Airbus-Boeing case, or by the hormones case, due to the fact that there is no stare decisis. Decisions do come part of the practice but, as suggested, an individual decision might not be suitable for every situation, even if the $A B$ tends to 'engage in farreaching interpretations' ${ }^{150}$. A final say of the members, without their possibility to veto a decision, might reduce criticism towards the $\mathrm{AB}$, and increase the incentive to comply with the rules of the organization, as further negotiations and the creation of norms would remain in their hands.

\footnotetext{
${ }^{148}$ See Article 22.15 of the agreement between US and Chile, or Art. 20.11 (5) of the agreement between US and Morocco.

${ }^{149}$ M. WAGNER, The impending demise of the WTO Appellate Body: from centrepiece to historical relic?, Faculty of Law, Humanities and the Arts - Papers. 4020. 2019, passim. Available online at https://ro.uow.edu.au/lhapapers/4020, last accessed at 01-12-2020.

${ }^{150}$ A. NARLIKAR, op. cit., p. 94
}

\section{1}




\section{Conclusion}

The WTO and its DSM can be compared with the jewel of the crown of the globalized international trade. States do tend to preserve their interests and chase the finest of margins, but only in exceptional cases they arrive to a situation where there is no going back. In such an extreme moment, it is inappropriate to leave the organization called to decide the issue without proper instruments. The fight against a procedure with more checks and fewer loopholes is a fight for a world where rules and principles, and not 'size and economic power' ${ }^{151}$ decide. A possibility to solve such issues is not a limitation of sovereignty and the triumph over principles of international law, but a mean to preserve balance ${ }^{152}$ between trading countries, and ensuring a hegemony of trade, and a hegemony of prosperity.

${ }^{151}$ C. P. Bown, D. A. Irwin, op. cit., p. 132.

152 M. Matsushita, A View on Future Roles of The WTO: Should There be More Soft Law in The WTO. Journal of International Economic Law, Vol. 17, no. 3, 2014, p. 715. 